\title{
Application of the Gómez-Muñoz model to estimate catch and effort in the artisanal fishery for the squid Loligo vulgaris (Mollusca: Cephalopoda) in the Ría de Vigo (NW Spain)
}

\author{
Natalia Comesaña, Ángel Guerra \\ Instituto de Investigaciones Marinas, CSIC, Eduardo Cabello 6, 36208 Vigo, Spain. \\ (NC) E-mail: nataliaccasal@ gmail.com. ORCID Id: https://orcid.org/0000-0001-8569-1477 \\ (AG) (Corresponding author) E-mail: angelguerra@iim.csic.es. ORCID iD: https://orcid.org/0000-0001-6716-3646
}

\begin{abstract}
Summary: The Gómez-Muñoz model was developed to aid the management of small-scale or artisanal fisheries and is based on interview data from fishermen and other personnel directly related to the fishery. The non-targeted and targeted Loligo vulgaris fishery in the Ría de Vigo and the Aldán Cove is explored. Eighty-one interviews were carried out. This survey yielded 38 valid interviews, which were used to estimate the parameters of the model for the period 2011-2015. Comparison between official landings and catches estimated by this model showed discrepancies varying between $41.8 \%$ and $98.4 \%$, depending on the fish markets considered. An $82.2 \%$ decrease of the squid catches over the period 2011-2015 was recorded. The reasons for that drop as well as the sensitivity and accuracy of the model are discussed.
\end{abstract}

Keywords: Loligo vulgaris; artisanal fisheries; total catch estimates; catch/effort estimates; Ría de Vigo; NW Spain.

Aplicación del modelo de Gómez-Muñoz para estimar capturas y esfuerzo en la pesquería artesanal del calamar Loligo vulgaris (Mollusca: Cephalopoda) en la Ría de Vigo (NO de España)

Resumen: El modelo de Gómez-Muñoz utiliza datos obtenidos a partir de entrevistas con los pescadores y otro personal relacionado con la pesquería. Se desarrolló para ayudar en la gestión de las pesquerías artesanales, en las que suele haber una deficiencia de datos sobre capturas y esfuerzos. En este trabajo se exploran la pesquería gallega que tiene como especie objetivo el calamar Loligo vulgaris, así como la que captura dicha especie de manera accidental en la Ría de Vigo y en la ensenada de Aldán. Se realizaron 81 entrevistas, de las cuales únicamente 38 se consideraron adecuadas para estimar los parámetros del modelo dentro del periodo 2011-2015. La comparación entre las descargas oficiales y las capturas estimadas por el modelo mostró discrepancias que variarion entre un $41.8 \%$ y un $98.4 \%$, dependiendo del puerto y lonja considerada. Se registró un descenso de las capturas de L. vulgaris del 82.2\% en el periodo 2011-2015. Se discuten las posibles causas de esta disminución de las capturas de calamar, así como la sensibilidad y precisión del modelo.

Palabras clave: Loligo vulgaris; pesquería artesanal; estimación de capturas totales; estimación de capturas/ esfuerzo; Ría de Vigo; NO de España.

Citation/Como citar este artículo: Comesaña N., Guerra A. 2019. Application of the Gómez-Muñoz model to estimate catch and effort in the artisanal fishery for the squid Loligo vulgaris (Mollusca: Cephalopoda) in the Ría de Vigo (NW Spain). Sci. Mar. 83(4): 305-316. https://doi.org/10.3989/scimar.04917.10A

Editor: R. Villanueva.

Received: February 8, 2019. Accepted: July 2, 2019. Published: September 18, 2019.

Copyright: ( 2019 CSIC. This is an open-access article distributed under the terms of the Creative Commons Attribution 4.0 International (CC BY 4.0) License.

\section{INTRODUCTION}

Small-scale fisheries (SSFs) are of great importance in terms of job opportunities and contribute significantly to the economy of many coastal com- munities (Natale et al. 2015). It has been estimated that SSFs generate approximately $53 \%$ of the direct jobs in the European Union (EU) catching sector, representing approximately $83 \%$ of the EU fishing vessels and $25 \%$ of the catch value (Guyader et al. 
2013). Spanish SSFs, with 8126 boats registered in 2015 and around 27000 direct jobs, are the most important ones of the EU. Within the Spanish SSFs, those of Galicia (NW Iberian Peninsula) take first place (CEPESCA 2015).

The Galician SSF comprising all types of fishing gears had a fleet of 4077 boats registered in 2015, with 586 having their homeports in the Ría de Vigo. This fleet, which targets a great variety of species, operates near the coast and is characterized by its heterogeneity, geographical mobility, and a complex alternation of fishing gear and target species. The fishing activities of that fleet are regulated by the authorization of official permits or "permex", which depends mainly on the success of the catches and bans (RAGG 2015). In Galician fishing grounds, the European squid Loligo vulgaris is mainly caught by boat seines, whose target species are pelagic fishes (sardine, mackerel and horse mackerel), the squid being only a by-catch. The only fishing gears whose target species are loliginids (L. vulgaris, Alloteuthis media and A. subulata) are beach seine ("boliche") and hand-jig (Xunta de Galicia 2004).

As a result of its complexity, the management of SSFs is challenging (Freire and García-Allut 2000), and the application of classical assessment methods used with cephalopod fisheries is problematic due to data limitations (Pierce and Guerra 1994). One of the limitations is the lack of reliable historical series of catches and catches per unit effort (CPUE). There are several procedures for overcoming this problem, one of them being the model of GómezMuñoz (1990), which was originally developed to aid the management of SSF for which catch and effort data may not be available. The method ulitilizes the knowledge of the fishermen and other people involved in the fishery, obtained through interviews, and is based upon two simple assumptions: that CPUE provides an index of stock size and that its trend over the course of a fishing season follows unimodal distribution, which can be normal, left- or right-skewed.

Application of this model to cephalopod SSFs has already proved useful in the small-scale fishery for the European squid (L. vulgaris) and veined squid (Loligo forbesii) in northern Spain, where no significant difference was found between CPUE values estimated from the model and those calculated from sales statistics (Simón et al. 1996). The model was also used in the SSF targeting the common octopus (Octopus vulgaris). Here, the average official catch from 1997 to 2000 and the estimated total catch data were not significantly different (Otero et al. 2005). Rocha et al. (2004) applied the model to the Galician monkfish (Lophius spp.) fishery in the Grand Sole area. Again, estimated CPUE did not differ significantly from values obtained directly from the fishery, although estimates of total catches from the model were around $12 \%$ higher than those obtained from fish market landings and sale invoices. More recently, Rocha et al. (2006) applied the model to the SSF of cuttlefish (Sepia officinalis) in 37 ports of Galicia (NW Spain). Here, the differences between the total catches estimated by the model and those determined directly at these ports were not significant. Finally, the model was also used in the veined squid (L. forbesii) fishery of Scotland (Young et al. 2006), where alternative parameterization was carried out. One of the results shown by these works was that the predicted catches were higher than the official figures, although similar trends were evident. These significant discrepancies between the official landing records and the real catches introduce a bias, which usually conceals fluctuations in the abundance of the species.

This paper used data collected on the squid $L$. vulgaris from the Ría de Vigo and the Aldán Cove. Data on the fishery were collected in interview surveys. The objectives of this work were to estimate the discrepancies between estimated catches from the model and the catches officially recorded, and to analyse the trend of catches and CPUEs between 2011 and 2015 in the Ría de Vigo and adjacent areas.

\section{MATERIALS AND METHODS}

\section{Study area}

The study area includes the Ría de Vigo, the Cove of Aldán and the adjacent continental shelf (Fig. 1). The main reason for this choice is that it is not possible to separate the origin of the European squid landings between these areas. In many cases, the same boats operate all over these areas, depending on the type of gear they use. The vessels that fish in these three areas do not report their catches jointly in the official statistics, but at different ports. However, the European squid of these three areas likely constitutes a unit of population, whose distribution is influenced by its trophic and reproductive migrations (Guerra and Rocha 1994, Simón et al. 1996, Moreno et al. 2015). The fish markets considered were Baiona, Canido, Cangas, Moaña, Panxón and Vigo (Fig. 1).

\section{Official data of European squid catches}

Data on official European squid landings in the fish markets from 1997 to 2015 (both inclusive) were downloaded from the website of the Plataforma Tecnolóxica de Pesca de Galicia (PTPG1 2016). Data were collected from all the fish markets of the Ría de Vigo and two fish markets of the Ría de Pontevedra (AldánHío and Bueu; Fig. 1). The calculated annual average corresponds to full calendar years(January-December).

\section{Interviews to calculate the Gómez-Muñoz model}

Appendix 1 shows the protocol followed in each interview. The interviewees included professional and sport fishermen, fish sellers, members of fishermen's associations and owners of bars 


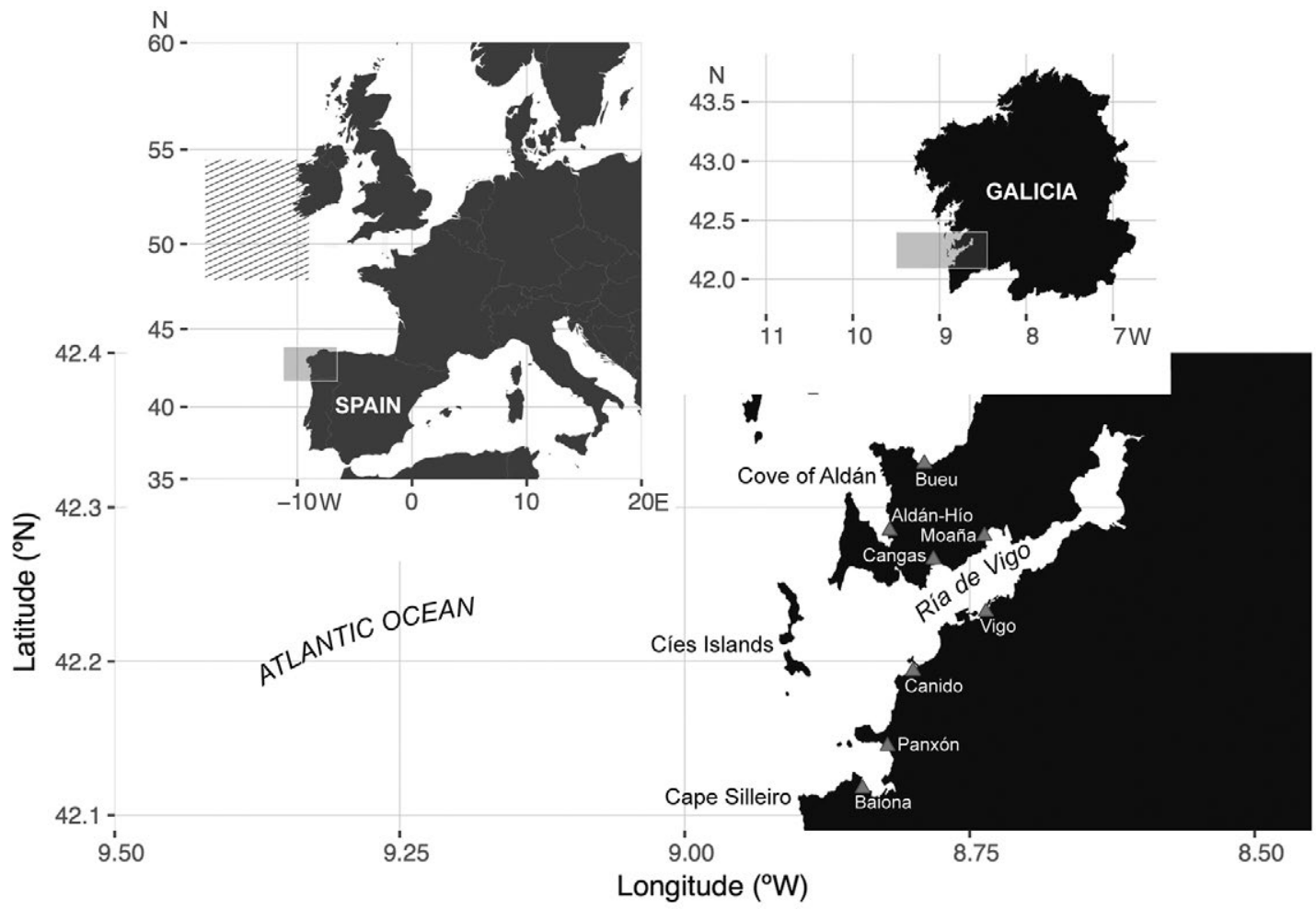

Fig. 1. - Map of the study area, composed of the Ría de Vigo, the Aldán Cove and the adjacent continental shelf, with the position of the ports where squid is landed. In striped pattern, Grand Sole fishing grounds where the Galician fishing fleet operates $\left(48^{\circ} \mathrm{N}-54^{\circ} 30^{\prime} \mathrm{N}\right.$. ICES Divisions VIIb, VIIc, VIIj, VIIk). (Source: Rocha et al. 2004).

who have fished or purchased L. vulgaris from the study area within the period 2011-2015. This period was chosen because the memory of the interviewees becomes too imprecise and unreliable beyond five years (Gómez-Muñoz pers. com.). In order to calculate the minimum number of interviews required for each fishing gear, the method proposed by Guerra and Sánchez Lizaso (1998) was used. It was assumed that the monthly catch $(\mathrm{kg})$ per trip $(\mathrm{Ct})$ fits to a bell-shaped distribution when the sample size is large enough (Rocha et al. 2004). A standard error of 5\% was accepted. However, when obtaining the minimum number of interviews required for that error was not possible, $10 \%$ or $15 \%$ were accepted. To calculate the maximum and minimum number of vessels using a certain gear, the official data recorded on the website of the Plataforma Tecnolóxica de Pesca de Galicia (PTPG2 2016) were taken into account as the maximum number.

This website provides the following information: i) the number of vessels registered in Galicia that have permission to fish with each type of gear ("permex"); ii) the types of gear that each vessel is allowed to use; iii) the fishing ground in which the vessels fish, and iv) the home port of each vessel. When the website of the Plataforma Tecnolóxica de Pesca did not have a registered gear (i.e. hand-jiggs), or there was evidence that the maximum number of vessels using a gear was much lower than the number of vessels with that "permex", we used the maximum reported in the interviews. In the case of hand-jig, fishing with this gear is carried out on foot or with recreational boats by sport fishermen or retirees and is therefore not officially recorded. The minimum number of vessels used was always the one obtained in the interviews.

Vessels (small boats) that own a "permex" to fish with small gillnets (racú and others) and small longlines (palangrillos) also have permissions to use others. In that scenario, fishermen use "permex" at their best convenience. Nevertheless, the interviews showed that the vessels that had "permex" for small gillnets used them preferentially. In this case, the minimum number of interviews required was calculated considering that the maximum number of vessels fishing with gillnets is equivalent to the number of vessels with "permex" for that fishing gear, and the minimum is the lowest possibility other than zero, that is, oneboat.

Non-valid interviews or "outliers" were discarded following the criteria of Rocha et al. (2004). In particular, it is not possible for $\mathrm{M}$ (parameter 6 in Appendix 1) to be before S (1) or after its end (S+L1); M must therefore lie during the fishing season. In other words, all observations that fulfil the requirement $\mathrm{M}<\mathrm{S}$ if $\mathrm{S}+\mathrm{L}<12$ or $\mathrm{M}+12>\mathrm{S}+\mathrm{L}$ were discarded. Owing to the uniformity of the catch distribution and the fact that the distribution of the maximum catch departs from normality, the statistical method of Tukey (1977) was used to exclude outliers from the interview data. Therefore, any $\mathrm{Cmax}$ per haul, vessel or trip was considered to be an outlier if it did not fall within the interval $\mathrm{Me}+\mathrm{G} 1.5 \mathrm{H}$, where $\mathrm{Me}$ is the 
Table 1. - Loligo vulgaris. Data used to calculate the minimum number of interviews and number of interviews conducted for each type of fishing gear. HJB, hand-jig from boat; HJL, hand-jig from land; MaxNV, maximum number of vessels; MinNIR, minimum number of interviews required; MinNV, minimum number of vessels; NIC, number of interviews conducted.

\begin{tabular}{|c|c|c|c|c|c|}
\hline Fishing gear & & MinNV & MaxNV & MinNIR & NIC \\
\hline HJB & & 58 & 71 & 2 & 9 \\
\hline HJL & Winter & 33 & 60 & 3 & 10 \\
\hline & Summer & 60 & 92 & 5 & \\
\hline Boliche & & 19 & 24 & 1 & 5 \\
\hline Boat seine & & 25 & 39 & 8 & 13 \\
\hline Racú & & 1 & 5 & 1 & 1 \\
\hline
\end{tabular}

median of the maximum catches and $\mathrm{H}$ the distance between the third (Q3) and the first (Q1) quartile of those catches.

\section{The Gómez-Muñoz model}

Eighty-one interviews were conducted between 15 April and 27 November 2015. Only 38 of them were introduced in the model. The selection was based on the criterion that all interviews had sufficient data and exceeded the minimum number required (Table 1). Appendix 2 shows the data obtained from these interviews. The CPUE (catch per trip, $\mathrm{Ct}$ ) and the total catch (TC) were calculated for a model year between 2011 and 2015 using the data collected from the interviews and following the steps indicated by Gómez-Muñoz (1990).

The first step is for the interviewee to determine whether, during the fishing season, the decrease of CPUE after the peak (I) was $\mathrm{I}=1$ (slow) $\mathrm{I}=2$ (medium) or $\mathrm{I}=3$ (fast), as seen in Figure 2. This datum will be used to transform the bell-shaped function $f(x)=e^{\wedge}(-$ $\left.x^{\wedge} 2 / 2\right)$ to obtain a curve of the monthly CPUE $(\mathrm{Ct})$.

In case of $I=1, f(x)$ is calculated with

$$
\mathrm{x}=[\mathrm{I}(\mathrm{t}-\mathrm{S})+\mathrm{Z}(\mathrm{t}-\mathrm{S}-\mathrm{L}+1)] /(\mathrm{L}-1)
$$

where $\mathrm{t}$ is a specific month within the fishing season $(\mathrm{t}=\mathrm{S}, \ldots, \mathrm{S}+\mathrm{L}-1)$ and $\mathrm{Z}$ the time elapsed between the start of the season and the month of maximum catch (M). $\mathrm{Z}$ is obtained with the equation

$$
\mathrm{Z}=(\mathrm{M}-\mathrm{S}) \mathrm{I} /(\mathrm{S}+\mathrm{L}-1-\mathrm{M})
$$

while if $I=2$ or $I=3$ occur, $f(x)$ will be calculated using

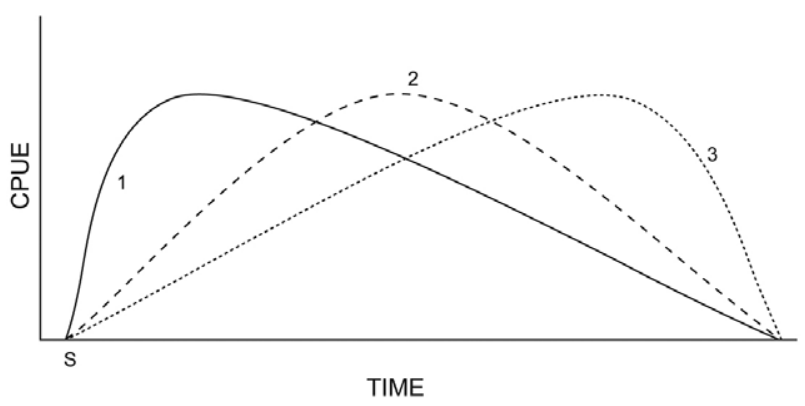

Fig. 2. - Types of rate of CPUE decrease after the peak in a fishing season. 1 slow; 2 , medium; 3 , fast. $\mathrm{S}$, month in which the fishing season starts.

$$
\mathrm{x}=[\mathrm{I}(\mathrm{t}-\mathrm{S}-\mathrm{L}+1)+\mathrm{Z}(\mathrm{t}-\mathrm{S})] /(\mathrm{L}-1)
$$

In this case $\mathrm{Z}$ corresponds to the time elapsed between $\mathrm{M}$ and the end of the season and is obtained with the equation

$$
\mathrm{Z}=\mathrm{I}(\mathrm{S}+\mathrm{L}-\mathrm{M}-1) /(\mathrm{M}-\mathrm{S})
$$

Once the value of $f(x)$ is known, the CPUE (catch per trip, $\mathrm{Ct}$ ) is estimated from

$$
\mathrm{Ct}=[\mathrm{Cmax}(\mathrm{f}(\mathrm{x})-\mathrm{f}(\mathrm{I}))+\mathrm{Cmin}(1-\mathrm{f}(\mathrm{x}) /[1-\mathrm{f}(\mathrm{I})]
$$

The values of $\mathrm{Ct}$ obtained will range within the values of $\mathrm{Cmin}$ and Cmax.

The method specified in Rocha et al. (2004) was used to determine the distribution of $\mathrm{Ct}$ and to calculate its standard error.

These data can be used to calculate the TC per port or area by means of several equations, depending on the information available. If the total number of trips made by the whole fleet $(\mathrm{V})$ is known, TC can be calculated with $\mathrm{TC}=\overline{\mathrm{C}} \cdot \mathrm{V}$, where $\overline{\mathrm{C}}$ corresponds to the mean value of $\mathrm{Ct}$, that is, $\overline{\mathrm{C}}=\Sigma \mathrm{Ct} / \mathrm{L}$. In $\mathrm{V}$ is not known, its value can be estimated by $\mathrm{V}=\mathrm{v} \cdot \mathrm{B} \cdot \mathrm{L}$, where $\mathrm{v}$ is the number of fishing trips per month made by each vessel and $B$ the number of vessels engaged in this fishing per type of fishing gear, resulting in $\mathrm{TC}=\overline{\mathrm{C}} \cdot \mathrm{v} \cdot \mathrm{B} \cdot \mathrm{L}$. However, the most accurate way to estimate the total catch is by multiplying the monthly CPUE per trip $(\mathrm{Ct})$ by $\mathrm{v}(\mathrm{t})$, which is the total number of trips per month, that is, $\mathrm{TC}=\Sigma \mathrm{Ct} \cdot \mathrm{v}(\mathrm{t})$.

\section{Comparison of the official landings in the fish markets with the results of the model}

We verified which percentage of the L. vulgaris catches is able to predict the Gómez-Muñoz model for the Ría de Vigo. To this end, the TCs of all fishing gears obtained by the model were added together. The reason for this addition is that the official landings data for each species are the result of the sum of all landings at each port, regardless of the fishing gear used or the place of origin of the fishery. Official data of landings were converted to annual, and the average for the study 5-year period (2011-2015) was calculated. The undeclared percentage is estimated afterwards.

\section{Estimation of the fishing effort}

The easiest method for measuring the effort made by the fleet of the L. vulgaris artisanal fishery is in number of trips. However, it should be taken into account that the characteristics of the trips differ depending on the fishing gear used. Some of these characteristics are the duration of the trip, the time of departure, the distance travelled and the area in which each fishing gear operates. In order to estimate the number of fishing trips per month made by each vessel and the total number of trips made by the whole fleet, we applied the method described in the Gómez-Muñoz model (Gómez-Muñoz 1990). 
Table 2. - Number and main characteristics of the vessels per fishing gear which yielded squid landings in the three areas over the study period. HJB, hand-jig from boat; Boliche, beach seine; BS, boat seine; GRT, gross register tonnage; HP, horse power.

\begin{tabular}{lllr}
\hline Fishing gear & NoV & GRT / HP & Observations \\
\hline HJB & 141 & $0.055-0.080 / 15$ & NoV obtained by adding the information of the interviews on each port. \\
\hline Boliche, Vigo & 67 & $39.84 / 28.32$ & $\begin{array}{r}\text { These figures are the vessels officially registered. Interviews and } \\
\text { Boliche, Aldán-Hio and Bueu }\end{array}$ \\
$\begin{array}{lll}\text { Peleteiro et al. (2008) reported that only between 19 and 24 of these } \\
\text { vessels were really operational, as shown in Table 1. }\end{array}$ & \\
Bacú & 39 & $72.35 / 39.84$ & \\
Rach & 5 & $4.70 / 41.25$ & \\
\hline
\end{tabular}

\section{RESULTS}

\section{Vessel characteristics}

Table 2 shows the number and main characteristics of the vessels per fishing gear which yielded squid landings in the three areas over the study period. Handjig from land is shown in Table 1.

\section{Official statistics}

Considering the fish markets of Baiona, Canido, Cangas, Moaña, Panxón and Vigo (Fig. 1), the $L$. vulgaris official landings in the whole Ría de Vigo between 1997 and 2015 (Fig. 3) displayed a seasonal pattern with maximum values in autumn and winter (black dots in Fig. 4). The distribution did not vary for the landings in the same fish markets over the

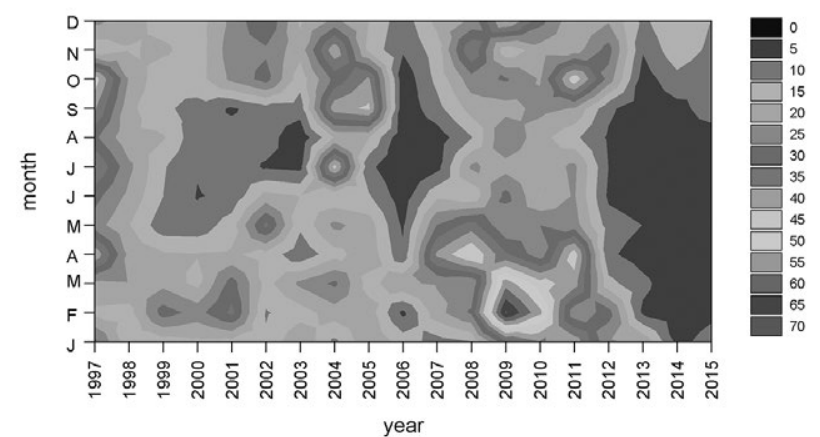

Fig. 3. - Loligo vulgaris. Seasonal and interannual variability of the official landings of squid $(\mathrm{kg})$ in the whole Ría de Vigo (fish markets of the ports of Baiona, Canido, Cangas, Moaña, Panxón and Vigo) between 1997 and 2015.

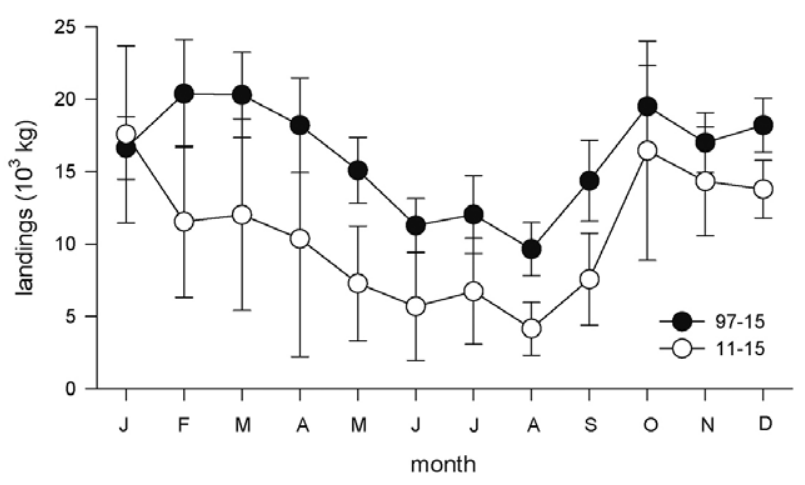

Fig. 4. - Loligo vulgaris. Monthly average and standard deviation of the official landings of squid $\left(10^{3} \mathrm{~kg}\right)$ in the whole Ría de Vigo (ports of Baiona, Canido, Cangas, Moaña, Panxón and Vigo) between 1997 and 2015 (black dots) and between 2011 and 2015 (white dots).

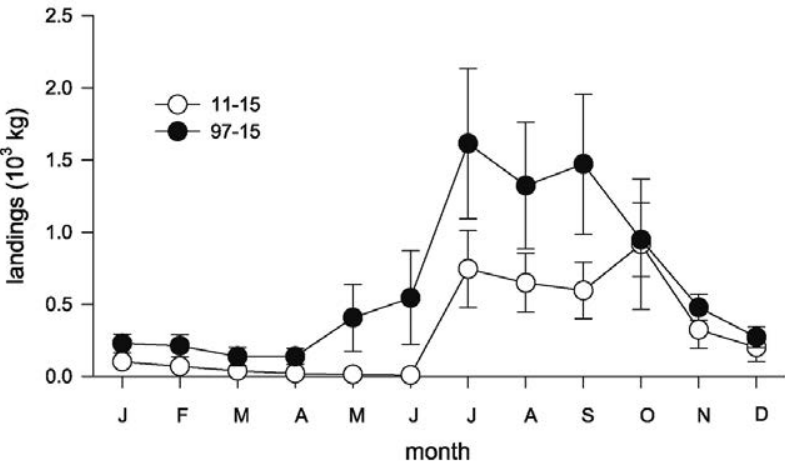

Fig. 5. - Loligo vulgaris. Monthly average and standard deviation of official landings of squid $\left(10^{3} \mathrm{~kg}\right)$ in the Ría de Vigo, excluding the landings from the fish market of the port of Vigo and including those of Aldán-Hio and Bueu, between 1997 and 2015 (black dots) and between 2011 and 2015 (white dots).

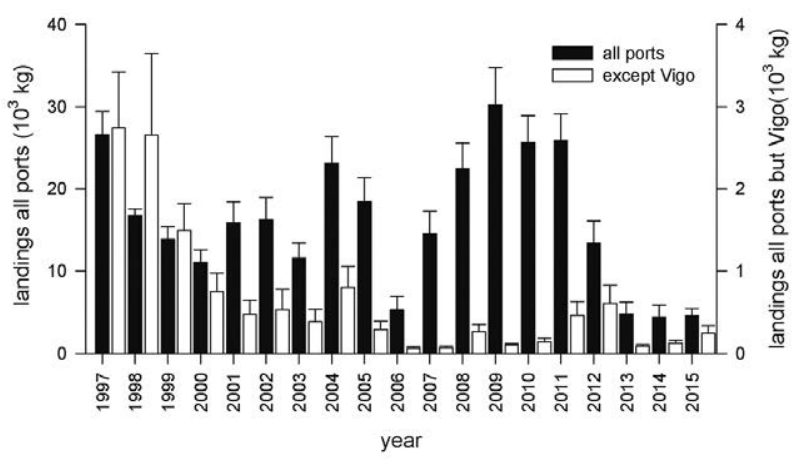

Fig. 6. - Loligo vulgaris. Annual average and standard deviation of official landings of squid $\left(10^{3} \mathrm{~kg}\right)$ in the whole Ría de Vigo (fish markets in the ports of Baiona, Canido, Cangas, Moaña, Panxón and Vigo) and in the Ría de Vigo after adding the Aldán-Hío and Bueu fish markets and subtracting the data from the fish market of the port of Vigo, 1997-2015.

period 2011-2015 (white dots in Fig. 4), when the interviews were applied. When the squid landings from the port of Vigo were removed and landings from the nearby ports of Aldán-Hío and Bueu (Fig. 1) were added, the distribution changed dramatically (Fig. 5). In this case, landings were concentrated almost exclusively between July and October for both the periods 1997-2015 (black dots) and 2011-15 (white dots).

The historical series of official landings shows that there was a decrease of $82.2 \%$ over the period 2011-15 (black bars in Fig. 6). After removing the official landings in the port of Vigo and adding the fish markets of Aldán-Hío and Bueu (white bars in Fig. 6), the decrease in the volume of landings was less pro- 
Table 3. - Loligo vulgaris. Ct (kg of squid per trip or CPUE) results of the Gómez-Muñoz model for each fishing gear and TC estimated in kilograms $(\mathrm{kg})$. M, month; HJL, hand-jig from land; HJB, hand-jig from boat; BAHB, boliche from Aldán-Hio and Bueu fishing ports; the boliche is a beach seine; BS, boat seine; $\mathrm{R}$, racú, which is a small gillnet.

\begin{tabular}{|c|c|c|c|c|c|c|c|}
\hline M & HJL & HJB & $\mathrm{BV}$ & BAHB & BS & $\mathrm{R}$ & TC \\
\hline 1 & 0.30 & 1.10 & 0.19 & 0.09 & 0.50 & 0.50 & 2.67 \\
\hline 2 & 0.36 & 1.29 & 0.19 & 0.09 & 0.81 & 3.73 & 6.46 \\
\hline 3 & 0.51 & 1.74 & 0.19 & 0.09 & 1.58 & 8.05 & 12.15 \\
\hline 4 & 0.81 & 2.60 & 0.19 & 0.09 & 3.13 & 13.37 & 20.18 \\
\hline 5 & 1.29 & 4.02 & 0.19 & 0.09 & 5.63 & 19.30 & 30.51 \\
\hline 6 & 1.88 & 5.94 & 0.19 & 0.09 & 8.70 & 25.22 & 42.01 \\
\hline 7 & 2.40 & 8.02 & 0.34 & 0.30 & 11.34 & 30.31 & 52.71 \\
\hline 8 & 2.60 & 9.67 & 4.67 & 6.36 & 12.40 & 33.77 & 69.47 \\
\hline 9 & 2.40 & 10.30 & 14.00 & 19.40 & 11.34 & 35.00 & 92.44 \\
\hline 10 & 1.88 & 9.67 & 4.67 & 6.36 & 8.70 & 33.77 & 65.05 \\
\hline 11 & 1.29 & 8.02 & 0.34 & 0.30 & 5.63 & 30.31 & 45.89 \\
\hline 12 & 0.81 & 5.94 & 0.19 & 0.09 & 3.13 & 25.22 & 35.37 \\
\hline Mean $\mathrm{Ct}$ & 1.38 & 5.69 & 2.11 & 2.78 & 6.08 & 21.55 & 6.59 \\
\hline $\mathrm{TC}(\mathrm{kg})$ & 15043.89 & 125190.63 & 11313.70 & 8883.07 & 41703.21 & 25855.55 & 227990.04 \\
\hline
\end{tabular}

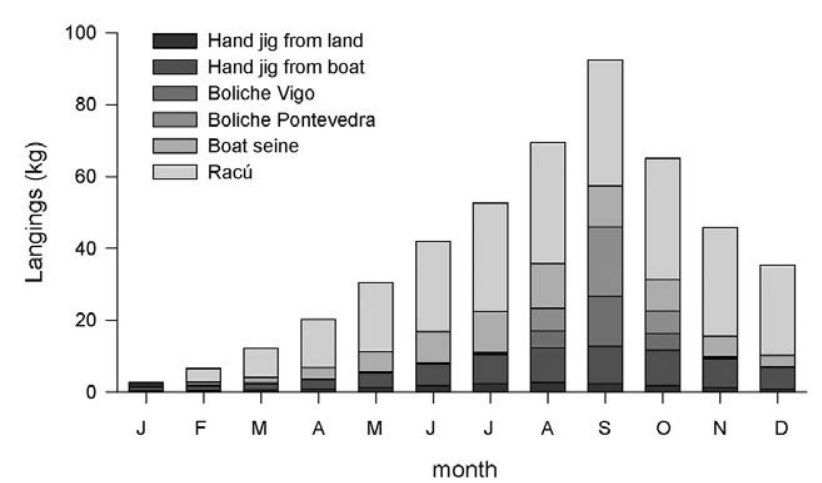

Fig. 7. - Loligo vulgaris. Monthly $\mathrm{Ct}$ (kg per trip or CPUE) of the set of fishing gears that operated in the Ría de Vigo and adjacent areas during the period 2011-2015 according to the Gómez-Muñoz model.

nounced $(71.5 \%)$. Considering the period 1997-2015, the reduction in landings would be $91.2 \%$.

On the other hand, the landings in the fish market of the port of Vigo throughout the study period (1997-2015) represented $95.9 \%$ of the total landings, varying between $84.1 \%$ (recorded in 1998) and $99.7 \%$ (recorded in 2009).

\section{The Gómez-Muñoz model}

According to the results obtained with this model (Table 3, Appendix 3), L. vulgaris caught using different fishing gears over the period 2011-2015 displayed a bell-shaped distribution, with minimum catches in the winter months and a peak between August and September (Fig. 7). It should be noted that the catch dis- tribution with beach seine differed strikingly from the others because fishing with this gear is only allowed from July to October (RAGG 2011). It can also be observed that beach seines and small gillnets, were the two fishing gears with the largest $C t$ in September.

Adding up the result obtained with the GómezMuñoz model for all fishing gears (Fig. 7), it is more apparent that fishing of European squid is carried out throughout the year and follows a bell-shaped distribution, the lowest values being in January and the highest in September.

Comparison between the results of the GómezMuñoz model and the official landings of the fish markets in the Ría de Vigo indicates that $41.8 \%$ of the catches would not have been declared. If the data of the landings in the port of Vigo are not taken into account and the landings from Aldán-Hío and Bueu are added, the model calculates a percentage of catches $98.4 \%$ higher than the average landings declared in the fish markets.

\section{Fishing effort and characteristics of the fishing trips by fishing gear}

The reported fishing effort (v), measured in number of fishing trips per month per boat, and total fishing effort (V), measured in number of trips made by the whole fleet, are shown in Appendix 2 and its average, calculated by the Gómez-Muñoz model, in Table 4 .

The hand-jig from land is mainly used during the hours of dawn and dusk along the coast, mainly from lit structures such as docks or bridges. The hand-jig from boat operates in the same hours, usually around headlands. Boat seine vessels sail one or two hours before

Table 4. - Average number of fishing trips per month per boat (v) and average number of trips made by the whole (V) by fishing gear. HJL, hand-jig from land; HJB, hand-jig from boat; Boliche, beach seine; BS, boat seine.

\begin{tabular}{|c|c|c|c|}
\hline Fishing gear & $\mathrm{V}$ & V & Observations \\
\hline HJL & 13 & 10920 & \multirow{2}{*}{$\begin{array}{r}\text { Fishing activities take place approximately } 20 \text { days per month from June } \\
\text { to September. The rest of the year } 10 \text { days per month. } \\
\text { It also depends on the weather. }\end{array}$} \\
\hline HJB & 13 & 21996 & \\
\hline Boliche, Vigo & 20 & 5360 & \multirow[t]{4}{*}{ Fishing activities take place from July to October. } \\
\hline Boliche, Aldán-Hio and Bueu & 20 & 3200 & \\
\hline BS & 16 & 6864 & \\
\hline Racú & 20 & 1100 & \\
\hline
\end{tabular}


sunset and return one or two hours after sunrise. They operate from the area surrounding the Cíes Islands up to $7 \mathrm{~km}$ into the Ría de Vigo. The beach seine vessels mainly fish near beaches during daylight hours and a trip can last from 4 to 8 hours. The racú is used in either day or night shifts, on the rocks very close to the shore and up to $13 \mathrm{~km}$ into the Ría de Vigo.

\section{DISCUSSION}

\section{Application of the Gómez-Muñoz model}

A variety of interview methods have been devised to elicit fisheries information when formal monitoring data are unavailable (e.g. Scholz et al. 2004, Jones et al. 2008). Fisheries of the European squid in the area studied lack the capacity to carry out formal monitoring, especially given that these fisheries are typically small-scale, use unofficial landing sites, and are usually multi-species and multi-gear (Xunta de Galicia 2004).

Interviews with harvesters where informants are asked to recall extraction over a period of time are often used to quantify use of wildlife resources (Wynne and Cote 2007). These surveys can generate information with less effort than more intensive methods such as daily interviews (Jones et al. 2008). However, little is known about the quality of the information reported in interviews with long recall periods and, hence, the same happens with their reliability as indicators of trends. We know of only one study that formally validates the results of rapid assessment interviews, which is about forest product harvesting with data on true levels of harvesting over a year (Gavin and Anderson 2005). In the present case, we decided that the data obtained from the interviewees represented their memory of up to five years before. Apart from the advice given by the model's author, this criterion was selected in this way after most of the people related to this fishery answered to the interviewer that approximately that was the period they could remember, and also because they answered that the decline of the squid fishery was about five or six years ago.

The first difficulty with the Gómez-Muñoz model occurred in collecting the interviews. We found that the interviews for different types of small gillnet and small longlines could not be used for two reasons: i) an excessive number of vessels with "permex" for these gears, and ii) limited information on how many vessels were actually using them and/or how regularly. This prevented us from calculating the minimum number of interviews required.

On the other hand, interviews with skippers, crews and other people related to the fishery provided a means to check the data obtained from logbooks or samples taken in the fish markets while we were collecting socio-economic data (Young et al. 2006). Compared with formal monitoring systems, the data obtained from the interviews are not independently verified and this may be a problem for their sensitivity. However, the interview system is less expensive than these monitoring systems or even than observation on board and, if handled sensibly, may help to build a rapport between scientists and fishermen (Young et al. 2006).

One of the problems of using interviews to check the status of any fishery is to address the reliability of data obtained from interviews and its use in monitoring trends. Numerous factors affect the reliability of the information reported in interviews, including misremembering and active misleading of the researcher (Bradburn et al. 1987). For some of these reasons, or because the interviews provided insufficient data or exceeded the minimum number required, $53 \%$ of the interviews obtained in this study were rejected (Table 1). As stated in the material and methods section, non-valid interviews or "outliers" were discarded following the criteria by Rocha et al. (2004). Despite the $53 \%$ reduction in the number of interviews, the 38 valid interviews were sufficient to meet the requirements of the number required for each type of fishing gear, which in total were 20 (Table 1). However, the greater the number of interviews, the more accurate estimates of model parameters are. It appears that the most reliable are the average values of the $\mathrm{Cmax}$ and Cmin, as well as the month when the Cmax is most frequently attained (Gómez-Muñoz 1990). Furthermore, if interviews are carried out on a monthly basis over a suitable period of time or during the season with the highest catch, the model parameters have a greater precision, generating more accurate estimates of catches.

In the study in which the model was first applied (Simón et al. 1996), two species of squid (L. vulgaris and $L$. forbesii) were caught in the NW of the Iberian Peninsula. However, since the early 1990s, L. forbesii has disappeared from much of the southern part of its former range, with catches off the Iberian Peninsula, for example, declining dramatically during the 1990s (Chen et al. 2006). In the present scenario our analysis was simplified by this fact. However, as the boliche catches both juveniles of L. vulgaris and Alloteuthis spp., the TC calculated for this fishing gear (Table 3) is overvalued.

Although here vessels or fishermen whose target species is L. vulgaris (hand-jig from boat and hand-jig from land) are analysed along with vessels and fishing gears that caught this species as by-catch (boliche, boat seine and racú), no special difficulties were encountered in obtaining the parameters used by the model with sufficient accuracy from valid interviews.

One aspect that should be taken into consideration is that, although in this harvesting all the fishing operations last one day, the real value of the fishing effort obtained (number of trips per day, $C t$ ) varies according to the characteristics of the boats or the capture being made on foot by a single fisherman.

Parameters 1, 2 and 6 (S, L and M, respectively, Appendix 1) of the Gómez-Muñoz model all involve similar units (months), so a comparison of the relative effects of these vectors on the results of the model is appropriate. However, the remaining parameters (excepting 7 and 8 , which are the minimum and maximum captures, Cmin and Cmax, respectively) have different dimensions, which can cause difficulties in interpreting 
the model. The units of these two parameters are given in kilograms per haul ( $\mathrm{kg} / \mathrm{haul})$ and a small variation in these parameters will obviously result in a large change in catches per unit of effort ( $\mathrm{Ct}$, Table 3$)$, making the results of the model very easily affected by them. Based on our experience with the interviewed fishermen, one of the most difficult parameters to obtain is the maximum catch per trip (Cmax). Given the sensitivity of the model to the Cmax parameter, in future work to be carried out in this area and with this species it would be very advisable to refine this parameter in the interview protocol.

Because there was no element of comparison, the accuracy of the model could not be calculated in the present paper. However, previous studies demonstrated that the model can estimate catches and CPUE accurately and reliably in both small-scale fisheries of cephalopod species (Simón et al. 1996, Otero et al. 2005, Rocha et al. 2006, Young et al. 2006) and largescale finfish fisheries (Rocha et al. 2004).

As in the above-cited studies, our analysis shows that the model-based estimates were significantly larger than those based on fish market receipts and invoices, indicating that our sampling approach yields better estimates of TC than those based on official statistics.

\section{Explanation of the trends of catches estimated with the model}

Results of the Gómez-Muñoz model indicated that the L. vulgaris catches are carried out throughout the whole year in the Ría de Vigo and adjacent area, although, as reflected in data collected both officially and from the interviews, they experience variations in abundance, geographic distribution and size of individuals throughout the year. This is mainly a consequence of the biological cycle of the species (Guerra and Rocha 1994, Moreno et al. 2015). Furthermore, European squid catches could also be influenced by other factors, such as the gear used or the climatological conditions. The decrease in the number of squid catches in winter coincides with i) an adverse meteorology that prevents fishing; ii) the absence of much of the L. vulgaris population, which withdraws to deeper waters of the continental shelf; and iii) the presence of only the largest European squids (Moreno et al. 2015, information obtained in the interviews). The increase in catches detected by the model, with its maximum in late summer and early autumn, corresponds to the recruitment period of the cohort born in the previous winter (December-February) and the return to the coast of the mature individuals for the egg-laying (Moreno et al.2015). The fact that beach seines and small gillnets are the fishing gears with the highest $\mathrm{Ct}$ (in September) is mainly due to i) the efficiency of the technique, capable of obtaining a larger number of catches in a shorter time; and ii) the coincidence of the area in which the fishing gear is used with the area in which the squid population is concentrated at that time, which is the interior of the Ría de Vigo (Xunta de Galicia 2004).

\section{Explanation of the discrepancies between the catches estimated from the model and the catches officially recorded}

Inconsistency was detected between the official squid landing data and the catches calculated using the interview model. Since the method used to estimate TC from the model always considers the maximum possible number of vessels, this estimate represents an upper limit of the capture, so the percentage discrepancies with official statistics are maximum estimates. Furthermore, the annual distribution of $\mathrm{Ct}$ coincides with that of the official landings data neither for the period 1997-2015 (Fig. 3 and black dots in Fig. 4) nor for the period 2011-15 (white dots in Fig. 4). While the records of official landings have two maxima, one in winter and the other in late summer-early autumn (white dots in Fig. 4), only the latter appears in the interview model (Fig. 7).

Given the suspicion that this maximum in winter reflected in the official annual landings was the product of squid landings in the port of Vigo from trawling in the Grand Sole, the staff of a fish marketing company from the port of Vigo were interviewed. This company trades with squid catches from both Grand Sole and the Ría de Vigo and adjacent area. The results of the interviews with workers of this company clearly indicated (data not shown) that the squid catches that arrive at the port from the Ría de Vigo are only acquired in the beach seine season, while those coming from outside the Ria de Vigo arrive throughout the year almost constantly and depend on the demand (not on the biological seasonality of the species), which increases slightly in summer. Regarding the proportion obtained from each source, the interviewees indicated that even in the beach seine season, L. vulgaris catches from the Ría de Vigo do not exceed 5\% of those coming from Grand Sole. In view of this, we decided to collect data of the official landings of the Ría de Vigo again adding the Aldán-Hío and Bueu fish markets and excluding the port of Vigo, which, in addition to having landings of L. vulgaris from Grand Sole, also had landings of Loligo forbesii in a proportion not evaluated. The platform PTPG1 (2016) began to distinguish $L$. vulgaris from L. forbesii ("lura colorada") landings only after 2015. With the new graph of official landings obtained by this procedure (Fig. 5 ), it was observed that, following the interview model (Fig. 7), the winter maximum did not exist, in contradiction with previous studies (Guerra and Rocha 1994) that showed L. vulgaris in the Ría de Vigo to have a bimodal seasonality, resulting from the appearance of two cohorts per year, one in winter and one in summer. Our results suggest that this discrepancy is due to an artefact caused by the type of fishing gears used to catch the species, which are not used in winter. In addition, the removal of the port of Vigo significantly reduced the volume of total squid catches, even though the Aldán-Hío and Bueu markets were included (Fig. $6)$. 
The difference obtained between the the official landings and the results of the Gómez-Muñoz model, or the undeclared percentage, was $98.4 \%$ for the ría without taking into account the port of Vigo but adding the Aldán-Hío and Bueu fish markets.

The fishing effort corresponding to each fishing gear (Table 4) may explain this incongruity. Though the number of fishing trips in a month per boat (v) was higher for the beach seine and racú, it was not the same for the total number of trips made by each whole fleet (V). In the case of the racú this is because, although it practically fishes throughout the year, it had a fleet of just five boats. In the case of the beach seine, it only operates from July to October. The hand-jig, both from land and from boat, showed the highest total number of trips because of the high number of fishers and vessels engaged in this type of fishing and the fact that they are active almost throughout the year. Thus, the fishing gear to which the majority of the total fishing effort corresponds would not be taken into account by the official statistics but by the Gómez-Muñoz model.

\section{Possible causes of the decrease in catches}

In this context, L. vulgaris catches may have decreased because a) there were fewer squids in the fishing grounds than in previous years; or b) the squid abundance was the same but they were less accessible to fishing gears, leading to decreased catchability. This tendency seemed to persist in the following years, 2016 and 2107, with a slight increase in 2018, as is reflected in the official landings (PTPG1 2016).

Data on the reduction of egg masses offered by the project CEFAPARQUES (Guerra et al. 2017), and the reduction of loliginid paralarvae collected with the multi-net trawl gear during the LARECO project (http://www.lareco.iim.csic.es), which dropped from 5.12 individuals $/ 1000 \mathrm{~m}^{3}$ to 1.3 individuals/1000 $\mathrm{m}^{3}$ between 2012 and 2014 (Olmos 2018), suggest that squid abundance in the Ría de Vigo has actually declined. This drop in abundance could be because i) natural mortality has increased, ii) fishing mortality has increased, and iii) L. vulgaris circumvent the Ría de Vigo for some reason.

The increase in natural mortality may have occurred. The mechanism could be as follows: under upwelling conditions loliginid larvae are retained in the water column (Roura et al. 2016), whereas they would be more dispersed in a downwelling situation occupying areas where conditions (particularly prey) were less favourable for their survival. This scenario of unfavourable conditions is supported by results showing that upwelling persistence and intensity have decreased over the last few decades (Âlvarez-Salgado et al. 2008, Pérez et al. 2010). In these conditions, trophic networks become more complex, and zooplankton biomass decreases (Bode et al. 2006), resulting in an unfavourable environment for $L$. vulgaris and thus increasing its natural mortality. However, this scenario could also support the hypothesis that the adults of $L$. vulgaris circumvent the Ría de Vigo and adjacent area and likely migrate further north into cooler waters, as apparently occurred in the case of Loligo forbesii in the Iberian Peninsula (Chen et al. 2006). Concerning fishing mortality, we observed a slight increase in the fishing effort targeting $L$. vulgaris during the course of the interviews to obtain the basic parameters of the model, so the influence of overfishing on the decrease of catches should not be ruled out, although it has not been addressed in this study.

\section{CONCLUSIONS}

We conclude that the Gómez-Muñoz model can produce independent estimates of catch/effort data based on interview data, which can be used to estimate effort and landings. However, there is a discrepancy of $41.8 \%$ between the officially declared landings in the Ría de Vigo and the catches estimated by the interview model when the landings in all fish markets are considered. The the figure rises to $98.4 \%$ when the Aldán-Hío and Bueu fish markets but not the port of Vigo are taken into account. The reasons for this discrepancy are that L. vulgaris catches from other fishing areas (mainly Grand Sole) are registered in the fish market of the port of Vigo and Loligo forbesii catches from Grand Sole are registered together with L. vulgaris catches. Finally, it was confirmed that there is a decrease in squid catches for the Ría de Vigo and adjacent area, which is estimated to be $82.2 \%$ for the period 2011-2015.

\section{ACKNOWLEDGEMENTS}

We would like to thank Francisco Rocha Valdés for his valuable advice on the application of the GómezMuñoz model, José Castro for his help in the accomplishment of many of the interviews, and Xose Antón Álvarez-Salgado for his help in the oceanographic information. We are indebted to our colleagues Lorena Olmos and Ángel F. González for their kindness in offering their unpublished data from the LARECO project.

\section{REFERENCES}

Álvarez-Salgado X.A., Labarta U., Fernández-Reiriz M.J., et al. 2008. Renewal time and the impact of harmful algal blooms on the extensive mussel raft culture of the Iberian coastal upwelling system (SW Europe). Harmful Algae 7: 849-855. https://doi.org/10.1016/j.hal.2008.04.007

Bode A., Alvarez-Ossorio M.T., Varela M. 2006. Phytoplankton and macrophyte contributions to littoral food webs in the Galician upwelling estimated from stable isotopes. Mar. Ecol. Prog. Ser. 318: 89-102. https://doi.org/10.3354/meps318089

Bradburn N.M., Rips L.J., Shevell S.K. 1987. Answering autobiographical questions - the impact of memory and inference on surveys. Science 236: 157-161. https://doi.org/10.1126/science.3563494

Chen C.S., Pierce G.J., Wang J., et al. 2006. The apparent disappearance of Loligo forbesi from the south of its range in the 1990s: Trends in Loligo spp. abundance in the northeast Atlan- 
tic and possible environmental influences. Fish. Res. 78: 44-54. https://doi.org/10.1016/j.fishres.2005.12.002

Confederación Española de Pesca (CEPESCA). 2015. Informe del sector pesquero español 2015. Oportunidades y desafíos. http:// cepesca.es/wp-content/uploads/2018/05/30.09.15-Informedel-sector-pesquero-espa\%C3\%B1ol-2015.pdf (Accessed the 24.11.16)

Freire J., García-Allut A. 2000. Socioeconomic and biological causes of management failures in European artisanal fisheries: the case of Galicia (NW Spain). Mar. Policy 24: 375-384. https://doi.org/10.1016/S0308-597X(00)00013-0

Gavin M.C., Anderson G.J. 2005. Testing a rapid quantitative ethnobiological technique: first steps towards developing a critical conservation tool. Econ. Bot. 59: 112-121.

https://doi.org/10.1663/0013-0001(2005)059[0112:TARQET] 2.0.CO;2

Gómez-Muñoz V.M. 1990. A model to estimate catches from a short fishery statistics survey. Bull. Mar. Sci. 46: 119-722.

Guerra A., Rocha F. 1994. The life history of Loligo vulgaris and Loligo forbesi (Cephalopoda: Loliginidae) in Galician waters (NW Spain). Fish. Res. 21: 43-69. https://doi.org/10.1016/0165-7836(94)90095-7

Guerra A., Sánchez Lizaso J.L. 1998. Fundamentos de explotación de recursos vivos marinos. Acribia, Zaragoza, $247 \mathrm{pp}$.

Guerra A., Hernández-Urcera J., Garci M.E., et al. 2017. Identificación y caracterización de Hábitats Esenciales para tres especies de cefalópodos en los Parques Nacionales de las Islas Atlánticas de Galicia y Cabrera. In: Armengol J. (ed). Proyectos de investigación en parques nacionales: 2012-2015. Organismo Autónomo de Parques Nacionales, MAPAMA, Naturaleza y Parques Nacionales. Serie Investigación en la Red, Madrid, pp. $13-43$.

Guyader O., Berthou P., Koutsikopoulos C., et al. 2013. Small scale fisheries in Europe: a comparative analysis based on a selection of case studies. Fish. Res. 140: 1-13. https://doi.org/10.1016/j.fishres.2012.11.008

Jones J.P.G., Andriamarovololona M.M., Hockley N., et al. 2008. Testing the use of interviews as a tool for monitoring trends in the harvesting of wild species. J. Appl. Ecol. 45: 1205-1212. https://doi.org/10.1111/j.1365-2664.2008.01487.x

Moreno A., Lefkaditou E., Robin J-P., et al. 2015. Loligo vulgaris. Cephalopod biology and fisheries in Europe: II. Species Accounts. ICES Coop. Res. Rep. 325: 114-135.

Natale F., Carvalho N., Paulrud A. 2015. Defining small-scale fisheries in the EU on the basis of their operational range of activity. The Swedish fleet as a case study. Fish. Res. 164: 286-292. https://doi.org/10.1016/j.fishres.2014.12.013

Olmos L. 2018. Ecology of cephalopod paralarvae in a seasonal upwelling system. PhD thesis, University of Vigo, $268 \mathrm{pp}$.

Otero J., Rocha F., González A.F., et al. 2005. Modelling artisanal coastal fisheries of Galicia (NW Spain) based on data obtained from fishers: the case of Octopus vulgaris. Sci. Mar. 69: $577-585$. https://doi.org/10.3989/scimar.2005.69n4577

Peleteiro J.B., Trujillo V., Bañón R., et al. 2008. Pesca, Marisqueo y Acuicultura en la Ría de Vigo. In: González-Garcés A., Vilas F., Álvarez-Salgado X.A. (eds), La Ría de Vigo. Una aproximación integral al ecosistema marino de la Ría de Vigo. Instituto de Estudios Vigueses, pp. 257-323.

Pérez F.F., Padín X.A., Pazos Y., et al. 2010. Plankton response to weakening of the Iberian coastal upwelling. Glob. Chang. Biol. 16: $1258-1267$ https://doi.org/10.1111/j.1365-2486.2009.02125.x

Pierce G.J., Guerra A. 1994. Stock assessment methods used for cephalopod fisheries. Fish. Res. 21: 255-285. https://doi.org/10.1016/0165-7836(94)90108-2

Platafoma Tecnoloxica de Pesca de Galicia (PTPG1). 2016. Principais indicadores de venta nas lonxas. Xunta de Galicia. Santiago de Compostela. Accesed at: http://www.pescadegalicia.gal/estadisticas/

Plataforma Tecnoloxica de Pesca de Galicia (PTPG2). 2016. Principais indicadores de venta nas lonxas. Xunta de Galicia. Santiago de Compostela. Accesed at: https://www.pescadegalicia.gal/rexbuque

Regional Autonomous Government of Galicia (RAGG). 2011. Diario Oficial de Galicia, 15th February 2011, No. 31. Xunta de Galicia. Santiago de Compostela, Spain.

Regional Autonomous Government of Galicia (RAGG). 2015. Diario Oficial de Galicia, 15th July 2015, No. 138. Xunta de Galicia. Santiago de Compostela, Spain.

Rocha F., Guerra A. 1996. Signs of an extended and intermittent terminal spawning in the squids Loligo vulgaris Lamarck and Loligo forbesi Steenstrup (Cephalopoda: Loliginidae). J. Exp. Mar. Biol. Ecol. 207: 177-189. https://doi.org/10.1016/S0022-0981(96)02631-7

Rocha F., Gracia J., González A.F., et al. 2004. Reliability of a model based on short survey fishery statistics: application to the monk fish Lophius spp. Galician fishery. ICES J. Mar. Sci. 61: $25-34$. https://doi.org/10.1016/j.icesjms.2003.10.006

Rocha F., Otero J., Outeiral R, et al. 2006. Modelling small-scale coastal fisheries of Galicia (NW Spain) based on data obtained from fisheries: the case of Sepia officinalis. Sci. Mar. 70: 593-601. https://doi.org/10.3989/scimar.2006.70n4593

Roura A., Álvarez-Salgado X.A., González A.F., et al. 2016. Life strategies of cephalopod paralarvae in a coastal upwelling system (NW Iberian Peninsula): insights from zooplankton community and spatio-temporal analyses. Fish. Oceanogr. 25: 241-258. https://doi.org/10.1111/fog.12151

Scholz A., Bonzon K., Fujita R., et al. 2004. Participatory socioeconomic analysis: drawing on fishermen's knowledge for marine protected area planning in California. Mar. Policy 28: 335-349. https://doi.org/10.1016/j.marpol.2003.09.003

Simón F., Rocha F., Guerra A. 1996. The small-scale squid hand-jig fishery off the northwestern Iberian Peninsula: application of a model based on short fishery statistics survey. Fish. Res. 25: 253-263. https://doi.org/10.1016/0165-7836(95)00425-4

Tukey J.W. 1977. Exploratory Data Analysis. Addison-Wesley Publishing Company, Reading, Mass. 506 pp.

Wynne S.P., Cote I.M. 2007. Effects of habitat quality and fishing on Caribbean spotted spiny lobster populations. J. Appl. Ecol. 44: 488-494. https://doi.org/10.1111/j.1365-2664.2007.01312.x

Xunta de Galicia. 2004. La pesquería de calamar (Loligo vulgaris) y puntilla (Alloteuthis spp.) en las Rías Baixas gallegas (19992003). Los Recursos Marinos de Galicia. Serie técnica, $\mathrm{n}^{\circ} 3$, Santiago de Compostela, 108 pp.

Young I.A.G., Pierce G.J., Murphy J., et al. 2006. Application of the Gómez-Muñoz model to estimate catch and effort in squid fisheries in Scotland. Fish. Res. 78: 26-38 https://doi.org/10.1016/j.fishres.2005.12.006 


\section{APPENDICES}

Appendix 1. - Questionnaire to obtain data about the European squid population of the study area.

Gómez-Muñoz interview

Interview No.:

Interview date:

Commercial:

Recreational:

Port:

\begin{tabular}{|c|c|c|c|}
\hline & & Interview & r name: \\
\hline Boliche & Boat seine & Trammel & Hand-jigs \\
\hline Hand-jig & rom boat or & from land & \\
\hline ldán, & Cangas, & Moaña, & Bueu, \\
\hline
\end{tabular}

Canido,

Panxón, Baiona

Basic parameters

1. $S$ : Month in which the fishing season starts (January=1)

2. L: Length of fishing season in months.

3. I: Rate of decrease in catches after the peak (1, slow; 2, medium; 3, fast).

4. $v$ : Number of fishing trips per month per boat (fishing effort)

5. $N$ : Number of hauls per boat per trip

6. $M$ : Month of maximum catch (peak of the fishery)

7. Cmin: Minimum catch in one haul $(\mathrm{kg} / \mathrm{h})$. A zero is not valid.

8. Cmax: Maximum catch in one haul $(\mathrm{kg} / \mathrm{h})$.

9. $B$ : Number of vessels engaged in this fishing per type of fishing gear.

10. $V$ : Total number of trips made by the whole fleet (total fishing effort)

Other information

The target species are Loligo vulgaris and/or Alloteuthis spp.

Fishing grounds.

Spawning grounds within the whole Ría de Vigo and Aldán Cove.

Spawning season.

Maximum and minimum sizes $(10 \mathrm{~cm}-45 \mathrm{~cm})$.

Behaviour.

Appendix 2. - Data obtained from interviews, used in the Gómez-Muñoz model. CF, commercial fishing; RF, recreational fishing. S, month in which the fishing season stars (January=1); L, length of fishing season in months; I, rate of decrease in catches after the peak (1, slow; 2, medium; 3, fast). v, number of fishing trips per month per boat (CPUE); N, number of hauls per boat per trip; M, month of maximum catch (peak of the fishery); Cmin, minimum catch $(\mathrm{kg})$ in one haul (a zero is not valid); Cmax, maximum catch (kg) in one haul; B, number of vessels engaged in this fishing per type of fishing gear; $\mathrm{V}$, total number of trips made by the whole fleet (total effort).

\begin{tabular}{|c|c|c|c|c|c|c|c|c|c|c|c|c|c|}
\hline Type & Gear & Port & From & $\mathrm{S}$ & $\mathrm{L}$ & I & $\mathrm{v}$ & $\mathrm{N}$ & $\mathrm{M}$ & $\mathrm{Cmin}$ & $\mathrm{Cmax}$ & B & $\mathrm{V}$ \\
\hline $\mathrm{RF}$ & Hand-jig & Vigo & Land & 6 & 12 & 3 & 20 & 50 & 8 & 0.1 & 3 & 3 & 7 \\
\hline RF & Hand-jig & Vigo & Land & 7 & 12 & 3 & 20 & 50 & 9 & 0.1 & 7 & 30 & 720 \\
\hline $\mathrm{RF}$ & Hand-jig & Baiona & Land & 7 & 5 & 3 & 20 & 50 & 8 & 0.1 & 5 & 20 & 200 \\
\hline RF & Hand-jig & Baiona & Land & 7 & 4 & 3 & 20 & 50 & 8 & 0.1 & 3 & 20 & 160 \\
\hline $\mathrm{RF}$ & Hand-jig & Vigo & Land & 6 & 12 & 2 & 4 & 90 & 9 & 0.1 & 1.4 & 30 & 144 \\
\hline RF & Hand-jig & Vigo & Land & 6 & 12 & 3 & 10 & 90 & 8 & 0.01 & 0.7 & 30 & 360 \\
\hline RF & Hand-jig & Vigo & Land & 6 & 12 & 2 & 20 & 90 & 9 & 0.5 & 3 & 30 & 720 \\
\hline RF & Hand-jig & Canido & Land & 6 & 7 & 2 & 20 & 90 & 9 & 0.5 & 2 & 10 & 140 \\
\hline RF & Hand-jig & Baiona & Land & 7 & 6 & 3 & 25 & 90 & 10 & 0.5 & 2 & 20 & 300 \\
\hline $\mathrm{RF}$ & Hand-jig & Cangas & Land & 1 & 12 & 2 & 20 & 90 & 8 & 0.5 & 4 & 10 & 240 \\
\hline RF & Hand-jig & Vigo & Boat & 7 & 12 & 3 & 20 & 50 & 11 & 3 & 15 & 30 & 720 \\
\hline $\mathrm{CF}$ & Hand-jig & Vigo & Boat & 6 & 4 & 3 & 20 & 90 & 9 & 0.1 & 5 & 30 & 240 \\
\hline $\mathrm{RF}$ & Hand-jig & Aldán & Boat & 7 & 4 & 3 & 24 & 50 & 8 & 0.2 & 25 & 20 & 192 \\
\hline $\mathrm{RF}$ & Hand-jig & Moaña & Boat & 6 & 12 & 3 & 20 & 40 & 8 & 0.1 & 10 & 35 & 840 \\
\hline RF & Hand-jig & Vigo & Boat & 6 & 12 & 2 & 4 & 90 & 9 & 0.1 & 0.5 & 30 & 144 \\
\hline RF & Hand-jig & Vigo & Boat & 6 & 12 & 3 & 12 & 90 & 9 & 0.1 & 7 & 30 & 432 \\
\hline RF & Hand-jig & Canido & Boat & 6 & 7 & 2 & 20 & 90 & 9 & 0.5 & 2 & 10 & 140 \\
\hline RF & Hand-jig & Baiona & Boat & 7 & 6 & 3 & 25 & 90 & 10 & 5 & 10.3 & 40 & 600 \\
\hline RF & Hand-jig & Cangas & Boat & 1 & 12 & 2 & 20 & 90 & 9 & 1.1 & 18 & 6 & 144 \\
\hline $\mathrm{CF}$ & Seine & Vigo & Boat & 1 & 11 & 3 & 16 & $1-10$ & 8 & 0.5 & 3 & 39 & 686 \\
\hline $\mathrm{CF}$ & Seine & Bueu & Boat & 1 & 11 & 3 & 16 & $1-10$ & 8 & 0.5 & 4 & 39 & 686 \\
\hline $\mathrm{CF}$ & Seine & Moaña & Boat & 1 & 11 & 3 & 16 & $1-10$ & 9 & 0.5 & 5 & 39 & 686 \\
\hline $\mathrm{CF}$ & Seine & Panxón & Boat & 1 & 11 & 3 & 16 & $1-10$ & 9 & 0.5 & 3 & 39 & 686 \\
\hline $\mathrm{CF}$ & Seine & Vigo & Boat & 1 & 11 & 2 & 16 & 8 & 8 & 0.5 & 20 & 39 & 686 \\
\hline $\mathrm{CF}$ & Seine & Bueu & Boat & 1 & 11 & 3 & 16 & $1-10$ & 10 & 0.25 & 25 & 39 & 686 \\
\hline $\mathrm{CF}$ & Seine & Bueu & Boat & 1 & 11 & 3 & 16 & $1-10$ & 2 & 0.5 & 17 & 39 & 686 \\
\hline $\mathrm{CF}$ & Seine & Bueu & Boat & 1 & 11 & 3 & 16 & $1-10$ & 11 & 0.4 & 23 & 39 & 686 \\
\hline $\mathrm{CF}$ & Seine & Bueu & Boat & 1 & 11 & 3 & 16 & $1-10$ & 8 & 0.75 & 15 & 39 & 686 \\
\hline $\mathrm{CF}$ & Seine & Bueu & Boat & 1 & 11 & 3 & 16 & $1-10$ & 12 & 0.75 & 12 & 39 & 686 \\
\hline $\mathrm{CF}$ & Seine & Bueu & Boat & 1 & 11 & 3 & 16 & $1-10$ & 8 & 0.75 & 2 & 39 & 686 \\
\hline $\mathrm{CF}$ & Seine & Redondela & Boat & 1 & 11 & 2 & 16 & $2-9$ & 8 & 0.5 & 22 & 39 & 686 \\
\hline $\mathrm{CF}$ & Seine & Vigo & Boat & 1 & 11 & 2 & 20 & $1-10$ & 8 & 0.5 & 10 & 39 & 858 \\
\hline $\mathrm{CF}$ & Boliche & Moaña & Boat & 7 & 4 & 3 & 20 & 15 & 9 & 0.1 & 20 & 10 & 800 \\
\hline $\mathrm{CF}$ & Boliche & Moaña & Boat & 7 & 4 & 3 & 20 & 6 & 8 & 0.1 & 10 & 10 & 800 \\
\hline $\mathrm{CF}$ & Boliche & Panxón & Boat & 7 & 4 & 3 & 20 & 19 & 8 & 0.5 & 15 & 1 & 80 \\
\hline $\mathrm{CF}$ & Boliche & Canido & Boat & 7 & 4 & 3 & 20 & 6 & 9 & 0.5 & 10 & 1 & 80 \\
\hline $\mathrm{CF}$ & Boliche & Cangas & Boat & 7 & 4 & 3 & 40 & 73 & 9 & 0.5 & 15 & 8 & 128 \\
\hline $\mathrm{CF}$ & Racú & Cang/Redon & Boat & 1 & 11 & 2 & 20 & 5 & 9 & 0.5 & 35 & 5 & 1 \\
\hline
\end{tabular}



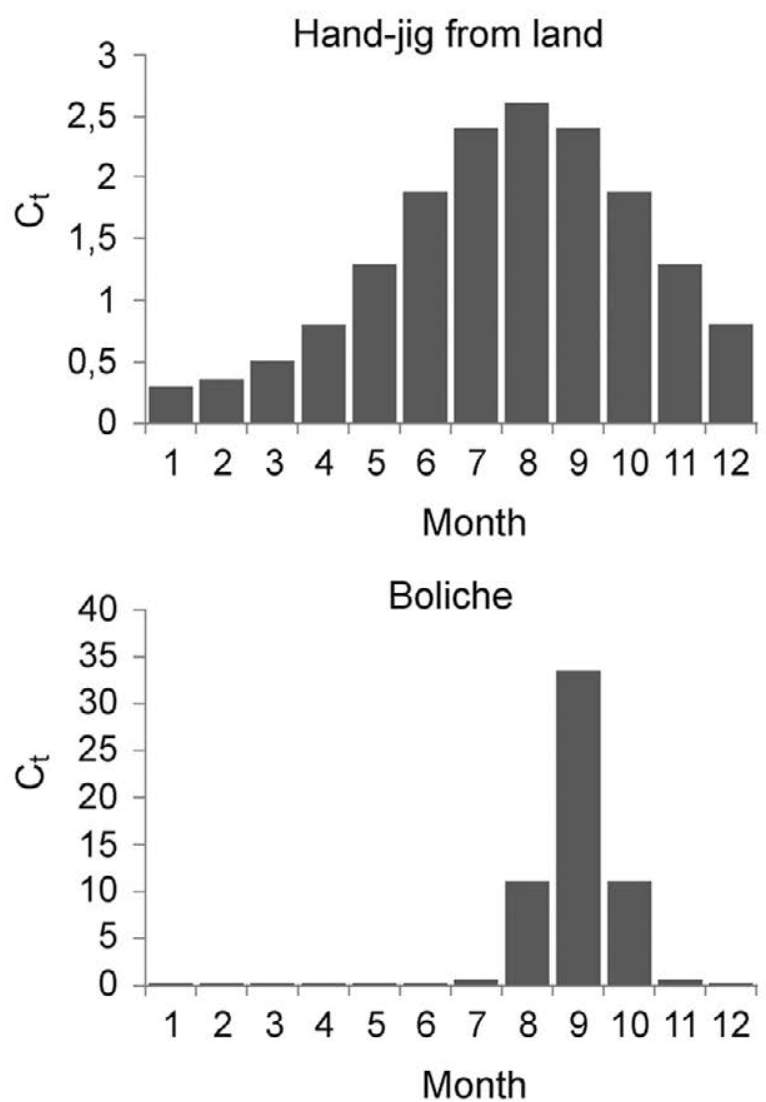
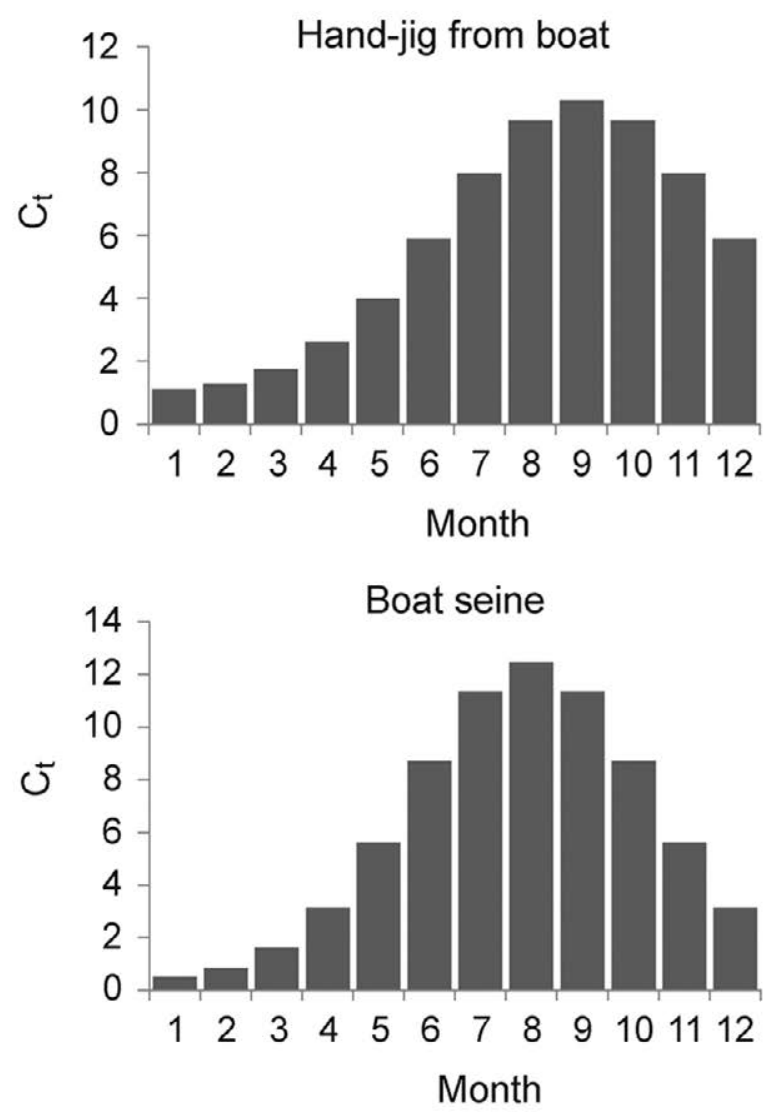

Racú

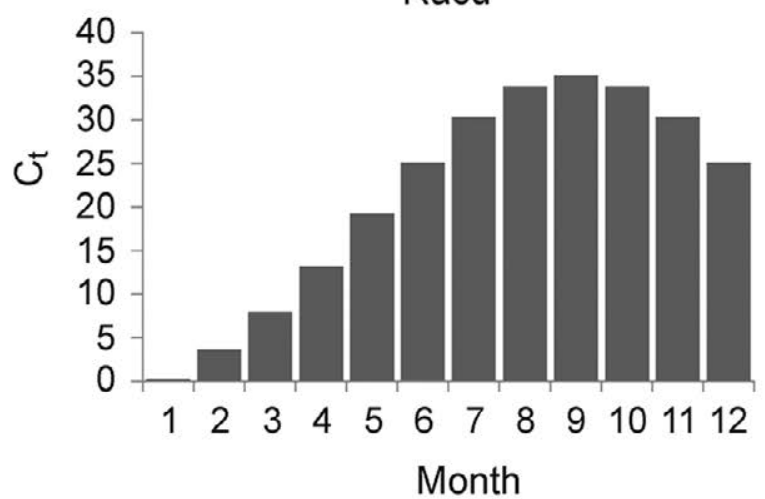

Appendix 3. - Ct (CPUE, kg of squid caught per trip) trend graphs of L. vulgaris in the Ría de Vigo for a model year (between 2011 and 2015) for each fishing gear, obtained by the model based on Gómez-Muñoz interviews. 